\title{
The Impact of Working Capital Management on Firm Performance across Bumiputera and Non Bumiputera Manufacturing Firms in Malaysia
}

\author{
NOR AZILA BINTI ABDUL HAMEER ${ }^{1}$, SURESH RAMAKRISHNAN², \\ SYED MUHAMMAD AHMAD HASSAN GILLANI ${ }^{3}$ \\ ${ }^{1}$ RAFFLES UNIVERSITY ISKANDAR, JOHOR BAHRU, JOHOR, MALAYSIA. E-mail: azihameer@gmail.com \\ ${ }^{2}$ Azman Hashim International Business School (AHIBS), UNIVERSITI TEKNOLOGI MALAYSIA. \\ ${ }^{3}$ Lyallpur Business School, GC UNIVERSITY FAISALABAD, PAKISTAN.
}

\begin{abstract}
Working Capital Management (WCM) plays a vital role in companies' both operational and financial decisions. WCM refers to all strategies adopted by the company to manage its short-term assets and short- term liabilities with the objective to ensure that it continues with its operations and meet its debt obligations when they fall due. There is lack of study being conducted on the effect of WCM on the profitability of firms in Malaysia, especially in manufacturing sector. Therefore, this study aims to investigate the relationship and the impact of WCM on firm performance across Bumiputera and Non-Bumiputera manufacturing firms in Malaysia. The analysis of panel data is conducted on sample size of 40 listed manufacturing firms from 2009 until 2018. This study employed descriptive statistics, correlation analysis and Pooled Ordinary Least Squares (OLS) to test the effect of inventory days, account receivable days, and account payable days (independent variable) on firm performance measured by return on assets (ROA). The findings show that there is significant negative relationship between inventory days and account receivable days on firm performance. While, account payable days shows an insignificant impact for both manufacturing firms and negative relationship on bumiputera firm performance and positive relationship on non-bumiputera firm performance. For future research, it is suggested that new the impact of WCM on firm performance in other sector in Malaysia can be measured.
\end{abstract}

Keywords: working capital management, firm performance, manufacturing sector.

JEL Classification: J

Recibido: 9 de Febrero de 2021

Aceptado: 17 de Marzo de 2021 


\section{Introduction}

Corporate finance theory can be discussed under three main areas: capital budgeting, capital structure and working capital management. Capital budgeting and capital structure decisions are related to financing and managing long-term investments and their returns. Working capital management is a very important component of corporate finance theory and deals with managing short-term financing and investment decisions of the firm. The corporate finance literature in the past has focused extensively on the study of long-term financial decisions, particularly investments, capital structure or company valuation decisions. However, working capital management also directly affects the liquidity of the company as it deals with the management of current assets and current liabilities that are essential for the smooth running of a business unit. Efficiency in working capital management is vital, especially for production firms as it accounts for over half of its total assets.

The objective of working capital management is to manage the firm's current assets and liabilities in such a way that a satisfactory level of working capital is maintained. The mismanagement of working capital may lead to a liquidity crisis and a reduction in profitability (Raza \& ul Haq, 2020). Haq et al. (2011) indicate that working capital management directly affects the profitability of a firm. Deloof (2003) emphasised that the way the working capital is managed has a significant impact on the profitability of firms. This implies that working capital management is one of the key decisions that a finance manager makes. Further, working capital is known as life-giving force for any economic unit and its management is considered among the most important function of corporate management. Every organisation whether profit oriented or not, irrespective of size and nature of business, requires necessary amount of working capital. Working capital management is one of the most important areas while making the liquidity and profitability comparisons among firms (Eljelly, 2004).

There are several studies investigate the impact of working capital on company performance which is (Singhania \& Mehta, 2017) pointed that working capital management component have negative and positive correlation with profitability where all component of working capital management effect the profitability. Besides that, several other researchers also adopted many theoretical to explain the firm behaviour and underpin the area of working capital. One of the theories that have been adopted to explain working capital management and firm performance is the cash conversion cycle (CCC) theory.

\section{Literature Review}

The profound understanding of the role of working capital and its effect on firm's profitability would help managers to look for strategic plans for management of working capital. One of the standard performance measures to evaluate how well a firm does managing the working capital is Cash Conversion Cycle (CCC). It refers to time-period between buying raw material, convert to finished goods, sales products, and collect account receivables. Firms with shorter cash conversion cycle have fewer investment in working capital and as a result the cost of financing are less for these firms. Cash conversion cycle integrates three components of management efficiency include, production, inventory management, as well as supply chain management (Ebrahim Mansoori, 2012).

According to Zariyawati et al. (2009) used panel data of 1,628 firm years for the period between 1996-2006 that consisted of six different economic sectors, in order to examine the relationship between working capital management and firm profitability of the firms listed in Malaysia. Results of this study found that the Cash Conversion Cycle (CCC) is significantly negatively associated with the firm profitability. They further emphasized that managers should focus on reduction of the cash conversion period in order to create shareholder wealth. The results of the study are consistent with that of other studies conducted in different markets. Moreover, Lou and Wang (2009) find that efficiency of a firm's working capital management has a lasting impact on the firm's performance. Improvement in working capital efficiency leads to increase in future earnings, as the market responds positively to the improvement of working capital efficiency. Firm value increases when CCC decreases.

Inventory Days (INV) reflects the average number of days of stock held by a firm. Longer storage times represent a greater investment in inventory for a particular level of operations. This variable 
refers to the number of days taken to hold stock before sold. Company success is partly depending on how effective the management manages their inventory. Huge inventory base and trade credit facilities may result to higher sales volume; and large amount of inventory in hand reduces the risk of a stock out. However, huge inventory level may lead to wastage if they cannot be sold. Empirical evidence showed that companies that have high number of obtained lower rates of return. The negative association between Inventory Days and firms' profit had been widely reported in the literature (Mohamad and Saad, 2010) which means that prolonging these cycles translated into a decrement in the profitability. In fact, Mansoori and Muhammad (2012) who examined Singapore firms found that all components of cash conversion cycle have a negative association with profitability. Napompech (2012) examined companies listed on the Thailand Stock Exchange identified that gross operating profit was inversely related to number of sales inventory days and the number of receivables days.

According to Falope and Ajilore (2009), receivables are related to the firm's credit collection policy, which also reflects the frequency of conversion of receivables into cash which is an important part of WCM. Account Receivable Days (AR) represents the number of days that a firm takes to collect payments from its customer. AR refers to the time taken to collect cash from the customers. A firm success is partly depending on how effective it manages the receivables. If the company makes fast collection of receivables, it may not have cash problem to maintain the operational costs. Longer credit term however, will attract customers to purchase from the company as compared to the competitor. Most empirical studies have shown that shorter AR leads to higher profit.

Account Payable Days (AP) refers to suppliers who had supplied goods or services that have not been paid by clients, which is also known as amount owing to creditors that is deemed as free credit. Basically, it indicates the average time firm takes to pay their suppliers. The higher the value, the longer firms take to settle their payment commitments to their suppliers. Payment period is the time taken to settle accounts payments. Quick payment allows the company to enjoy cash discount and maintain good reputation with supplier. Delaying payment to the accounts payable however, enable company to use the cash for generating returns but it may jeopardize relationship with supplier and lost the cash discount. Both approaches may have impact on the company's financial performance. Existing evidence shows negative association between accounts payable days (AP) and profit (Ahmadpour et al., 2012; Mansoori \& Muhammad, 2012; Mohamad \& Saad, 2010; Singhania et al., 2014). It suggests that firm's profit will increase if firms are fast in paying its account payable.

\section{Methodology}

The secondary data was used in this study. The data was retrieved from Bursa Malaysia (KLSE) in Malaysia from 2009 until 2018. Besides that, the sample consists of 40 manufacturing firms which consist of bumiputera and non-bumiputera manufacturing firms in Malaysia that are listed in the Bursa Malaysia. As at 2018, there were top 100 manufacturing firms listed in the Main Market of Bursa Malaysia based on their top gainers, stock performance, top turnover and total sales. Thus, after taken into consideration removal of firms with missing or incomplete data from the population, the sample of the study consists of 40 firms listed under manufacturing sector with 10 bumiputera firms and 30 non-bumiputera firms was selected based on the study period from 2009 to 2018 . Furthermore, this study adopted the census sampling method, where all the bumiputera and non-bumiputera manufacturing firms were explored. Firstly, descriptive statistics is employed to check the basic nature of data, then correlations matrix is developed to know basic relationship between independent variables and independent. Finally, pooled ordinary square (OLS) is employed to investigate working capital management on firm performance. 


\section{Result and Discussion}

The summary of the key descriptive statistics for the dependent and independent variables are summarized in Table 4.1 below, which presents descriptive statistics for 40 manufacturing firms for a period of ten years from 2009 to 2018.

Table 4.1: Summary of Descriptive Statistics for Bumiputera and Non-Bumiputera Firms in Manufacturing Sector

\begin{tabular}{|c|c|c|c|c|c|}
\hline Variable & Observations & Mean & Maximum & Minimum & Std Deviation \\
\hline ROA & 400 & 0.13 & 4.15 & -0.63 & 0.26 \\
\hline INV & 400 & 75.1 & 1232.1 & 4.4 & 102.33 \\
\hline AR & 400 & 89 & 1187.3 & 4.2 & 103.42 \\
\hline AP & 400 & 88.3 & 962.1 & 6.8 & 89.5 \\
\hline SIZE & 400 & 13.6 & 18.68 & 9.8 & 1.77 \\
\hline GROWTH & 400 & 0.03 & 0.92 & -7.7 & 0.5 \\
\hline
\end{tabular}

This table demonstrate the mean, standard deviation, minimum and maximum based on bumiputera and non-bumiputera manufacturing company in Malaysia. The overall sample are $10 \mathrm{firm}$ year observation from 2009 until 2018. The dependant variable is return on assets (ROA) while the independent variables used in this study are inventory days (INV), account receivable days (AR) and account payable days (AP). Firm size (SIZE) and sales growth (GROWTH) used as control variables.

Based on Table 4.1, the average profit of the both manufacturing firms as indicated by ROA is $13 \%$. The minimum value for ROA is reported as negative $63 \%$ with maximum value of $415 \%$, whereby the standard deviation of ROA is indicated as $26 \%$, which means that ROA value can deviate from mean of both sides by $26 \%$.

For WCM components, noted that AR has reported the highest mean value of 89 days, followed by AP with average of 88 days and INV recorded an average of 75 days. These reflect that manufacturing firms receive payment from sales proceeds on average of 89 days with standard deviation of 103 days, which the minimum collection period from receivables proceeds is 4 days with maximum period of 1187 days. Furthermore, firms take an average of 75 days to sell inventory with standard deviation of 102 days. Meanwhile, firms pay their purchases an average of 88 days with standard deviation of 89 days, which the minimum period reported as 6 days and maximum period is 962 days. The mean size of bumiputera and non-bumiputera manufacturing firms is reported as 13.6. Meanwhile, the average sales growth is $3 \%$. The summary of the key descriptive statistics for the dependent and independent variables are summarized in Table 4.2, which presents descriptive statistics for manufacturing firms for a period of ten years from 2009 to 2018, which has a total of 10 bumiputera firms and 30 nonbumiputera firms.

Table 4.2: Summary of Descriptive Statistics for Bumiputera Firms in Manufacturing Sector

\begin{tabular}{|c|c|c|c|c|c|}
\hline Variable & Observations & Mean & Maximum & Minimum & Std Deviation \\
\hline ROA & 100 & 0.073 & 0.34 & -0.63 & 0.14 \\
\hline INV & 100 & 89.05 & 1232.1 & 19.2 & 134.35 \\
\hline AR & 100 & 90.4 & 240.7 & 18 & 42.7 \\
\hline AP & 100 & 112.61 & 529.1 & 23.5 & 77.9 \\
\hline SIZE & 100 & 14.16 & 18.68 & 10.97 & 2.15 \\
\hline GROWTH & 100 & 7.15 & 479.35 & -79.40 & 53.4 \\
\hline
\end{tabular}

This table demonstrate the mean, standard deviation, minimum and maximum based on bumiputera manufacturing company in Malaysia. The overall sample are 10 firm-year observation from 2009 until 2018. The dependant variable is return on assets (ROA) while the independent variables used in this study are inventory days (INV), account receivable days (AR) and account payable days (AP). Firm size (SIZE) and sales growth (GROWTH) used as control variables.

Based on Table 4.2, the average profit of the Bumiputera manufacturing firms as indicated by ROA is $7.3 \%$. The minimum value for ROA is reported as negative $63 \%$ with maximum value of $34 \%$, whereby 
the standard deviation of ROA is indicated as $14 \%$, which means that ROA value can deviate from mean of both sides by $14 \%$. For WCM components, noted that AP has reported the highest mean value of 112 days, followed by AR with average of 90 days and INV recorded an average of 89 days. These reflect that manufacturing firms receive payment from sales proceeds on average of 90 days with standard deviation of 43 days, which the minimum collection period from receivables proceeds is 18 days with maximum period of 241 days. Furthermore, firms take an average of 89 days to sell inventory with standard deviation of 134 days. Meanwhile, firms pay their purchases an average of 112 days with standard deviation of 78 days, which the minimum period reported as 24 days and maximum period is 529 days. The mean size of bumiputera manufacturing firms is reported as 14.16 . Meanwhile, the average sales growth is $715 \%$. The summary of the Pooled OLS analysis is presented in table 4.3 , table 4.4 and table 4.5. These tables highlight the pooled OLS analysis between the working capital and firm performance across bumiputera and non-bumiputera manufacturing firms in Malaysia.

The following equation was used to determine the impact between the performance and working capital components.

Model 1: The effect of WCM on profitability of firms

$$
R O A_{i, t}=\beta_{0}+\beta_{1} I N V_{i, t}+\beta_{2} A R_{i, t}+\beta_{3} A P_{i, t}+\beta_{4} S I Z E_{i, t}+\beta_{5} G R O W T H_{i, t}+\varepsilon_{i, t}
$$

Table 4.3: Panel Data Regression Analysis of Bumiputera and Non-Bumiputera Firms in Manufacturing Sector

\begin{tabular}{|c|c|c|}
\hline Dependant Variables & \multicolumn{2}{|c|}{ Model 1: ROA } \\
\hline Variables & Coefficient & p-value \\
\hline INV & -0.000448 & $0.001^{*}$ \\
\hline AR & -0.000331 & $0.037^{*}$ \\
\hline AP & 0.000228 & 0.205 \\
\hline SIZE & -0.00319 & 0.667 \\
\hline GROWTH & -0.04147 & 0.116 \\
\hline const & 0.21904 & 0.036 \\
\hline
\end{tabular}

This table indicate the coefficient and $p$-value of variables using STATA software. The analysis is based on bumiputera and non-bumiputera manufacturing company in Malaysia. The overall sample are 40 firm-year observation from 2009 until 2018. The dependant variable is return on assets (ROA) while the independent variables used in this study are inventory days (INV), account receivable days (AR) and account payable days (AP). Firm size (SIZE) and sales growth (GROWTH) used as control variables.

Table 4.4: Panel Data Regression Analysis of Bumiputera Firms in Manufacturing Sector

\begin{tabular}{|c|c|c|}
\hline Dependant Variables & \multicolumn{2}{|c|}{ Model 1: ROA } \\
\hline Variables & Coefficient & p-value \\
\hline INV & -0.0001313 & 0.186 \\
\hline AR & -0.0008436 & $0.006^{*}$ \\
\hline AP & -0.0001267 & 0.446 \\
\hline SIZE & 0.193902 & 0.002 \\
\hline GROWTH & -0.0001355 & 0.558 \\
\hline const & -0.0984432 & 0.272 \\
\hline
\end{tabular}

As shown in Model 1, for both bumiputera and non-bumiputera firms in manufacturing sector, inventory days (INV) had negative significant impact on return on asset (ROA) at $1 \%$ level significant with $p$-value 0.001 . Similarly, account receivable days (AR) had negative significant impact on return on assets (ROA) at $1 \%$ level significant with $p$-value 0.006 . This result revealed that an increase in the accounts receivable days (AR) by a day has reduced the firm's ROA, which the result is consistent with the other previous literature review conducted that had also revealed a significant negative relationship between profitability and AR (Falope \& Ajilore, 2009; Gill, Biger \& Mathur, 2010; Dong \& $\mathrm{Su}, 2010)$. Therefore, the hypothesis of $\mathrm{H} 1$ and $\mathrm{H} 2$ is failed to reject. 
This table indicate the coefficient and p-value of variables using STATA software. The analysis are based on bumiputera manufacturing company in Malaysia. The overall sample are 10 firm-year observation from 2009 until 2018. The dependant variable is return on assets (ROA) while the independent variables used in this study are inventory days (INV), account receivable days (AR) and account payable days (AP). Firm size (SIZE) and sales growth (GROWTH) used as control variables.

As shown in Model 1, for bumiputera firms in manufacturing sector, account receivable days (AR) had negative significant impact on return on assets (ROA) at $1 \%$ level significant with $p$-value 0.006 . This result revealed that an increase in the accounts receivable days (AR) by a day has reduced the firm's ROA, which the result is consistent with the other previous literature review conducted that had also revealed a significant negative relationship between profitability and AR (Falope \& Ajilore, 2009; Gill, Biger \& Mathur, 2010; Dong \& Su, 2010). Therefore, the hypothesis of H2 is failed to reject. While size of the firm (SIZE) had significant positive relationship with positive significant impact on ROA at $1 \%$ significant level with $p$-value 0.002 , which the results are consistent with other previous studies conducted by Raheman, Afza, Qayyum \& Bodla (2010); Akinlo (2012). This indicates that the larger the size of the firms, the higher the profitability achieved as the firms are able to reap the benefit of economies of scales and obtain easier funding to expand the business. To conclude, the result of pooled OLS analysis on bumiputera manufacturing firms indicate that firm size had positive significant impact and account receivable days (AR) had negative significant impact on the firm performance.

Table 4.5: Panel Data Regression Analysis of Non-Bumiputera Firms in Manufacturing Sector

\begin{tabular}{|c|c|c|}
\hline Dependant Variables & \multicolumn{2}{|c|}{ Model 1: ROA } \\
\hline Variables & Coefficient & p-value \\
\hline INV & -0.0004686 & $0.019^{*}$ \\
\hline AR & -0.0003952 & $0.043^{*}$ \\
\hline AP & 0.0004666 & 0.060 \\
\hline SIZE & -0.0107269 & 0.341 \\
\hline GROWTH & -0.000116 & 0.599 \\
\hline const & 0.3297048 & 0.035 \\
\hline
\end{tabular}

This table indicate the coefficient and $p$-value of variables using STATA software. The analysis are based on non-bumiputera manufacturing company in Malaysia. The overall sample are 30 firm-year observation from 2009 until 2018. The dependant variable is return on assets (ROA) while the independent variables used in this study are inventory days (INV), account receivable days (AR) and account payable days (AP). Firm size (SIZE) and sales growth (GROWTH) used as control variables.

As shown in Model 1, for non-bumiputera firms in manufacturing sector, inventory days (INV) and account receivable days (AR) had negative significant impact on return on assets (ROA) at $5 \%$ level significant with $\mathrm{p}$-value 0.019 and 0.043 respectively. Therefore, hyphotesis of $\mathrm{H} 1$ and $\mathrm{H} 2$ are fail to reject. However, for other variables, account payable days (AP) has a positive relationship with ROA, but the relationship is not significant. This implies that ROA has increased by lengthening a day of the accounts payable days (AP). Although the result obtained contradicts with some of the earlier studies that revealed a negative relation between AP and profitability (Falope \& Ajilore, 2009), however, the result is supported by study conducted by Dong \& Su (2010), who had found a significant positive association between AP and profitability, which means that there is a delay in payment by firms with higher profitability. Furthermore, the increase in AP may increase the firm's profitability partly due to well established firms are given longer trade credit terms by their suppliers due to their long business relationship and most of their purchases are in bulk orders. Thus, based on the result obtained above, the hypothesis of $\mathrm{H} 3$ is rejected due to despite that there is a positive relationship, however, the relationship is not significant between AP and ROA of the non-bumiputera firms under manufacturing sector.

As for the control variables, size of firms (SIZE) and sales growth (GROWTH) had insignificant impact on ROA. Meanwhile, an insignificant negative relationship between sales growth (GROWTH) and ROA contradict with the previous literature review that found a positive association between GROWTH and 
profitability of firms (Akinlo, 2012; Zariyawati, Annuar, Taufiq \& Abdul Rahim, 2009; Raheman, Afza, Qayyum \& Bodla, 2010). To conclude, the result of pooled OLS analysis on non-bumiputera manufacturing firms indicate that WCM had negative significant impact on the firm performance.

From all the above analysis, inventory days (INV) has insignificant impact on the performance in the bumiputera manufacturing firms but has negative significant impact on ROA in the non-bumiputera manufacturing firms and also for overall manufacturing firms. This result aligns with Mohamad et al. (2016) that stated decreased inventory conversion will increase profitability. As for account receivable days (AR), it shows negative significant impact on ROA in both bumiputera, non-bumiputera and overall manufacturing firms. Based on the results derived in Table 4.3, 4.4 and 4.5, it is suggested that the firm's finance manager can increase the profitability of the firm in manufacturing sector by reducing the $A R$, that represent part of the WCM components that reveals a significant negative relationship with profitability of the firms, which is measured by ROA. In the bumiputera manufacturing firms, firm size (SIZE) as control variable shows positive significant impact on ROA. However, other variables did not show any significant impact on the firm performance in both bumiputera and non-bumiputera manufacturing firms.

\section{Conclusion and Implication}

As a summary, this study concentrates on the relationship and impact of WCM on firms' performances across bumiputera and non-bumiputera firms in Malaysia. The correlation analysis shows that part of WCM components are significantly related to firm performances for both firms. While pooled OLS analysis result also show some significant impact between the variables. However, both analysis show different results. This study used the result from pooled OLS analysis to determine the impact of WCM on firm performance across bumiputera and non-bumiputera manufacturing firms in Malaysia. This study may be useful to finance managers and operational managers of manufacturing firms to improve firm working capital mechanism. Secondly the implication of this study is to take appropriate decision by credit managers of financial institution like banking sector while they are interested to give short term credit facility to manufacturing firms especially in Malaysia because good Woking capital management is very important factor for banking sector while making credit decision.

\section{References}

1. Ahmadpour, A., Zare, M. J., \& Rostami, K. H. (2012). An empirical study of association between working capital management and performance: Evidence from Tehran stock exchange. Journal of Social and Development Sciences, 3(8), 279-285.

2. Akinlo, O.O. (2012). Effect of working capital on profitability of selected quoted firms in Nigeria. Global Business Review, 13(3), 367-381.

3. Alipour, M. (2011). Working capital management and corporate profitability: Evidence from Iran. World Applied Sciences Journal, 12(7), 1093 - 1099.

4. Deloof, M. (2003). Does working capital management affect profitability of Belgian firms? Journal of Business Finance \& Accounting, 30(3) \& (4), 573-588.

5. Deloof, M. and Jeger, M. (1996). Trade Credit, Product Quality and Intragroup Trade: Some European Evidence. Financial Management, 25(3), 945-968.

6. Dong, H. P. and Su J.T. (2010). The relationship between Working Capital Management and Profitability. A Vietnam case. International Research Journal of Finance and Economic, 49(49), 5967.

7. Eljelly, A. (2004). Liquidity - profitability tradeoff: An empirical investigation in an emerging market. International Journal of Commerce and Management, 14(2), 48-61.

8. Falope, O.I. and Ajilore, O.T. (2009). Working capital management and corporate profitability: Evidence from panel data analysis of selected quoted companies in Nigeria. Research Journal of Business Management, 3(3), 73-84. 
9. Gill, A., Biger, N. and Mathur, N. (2010). The Relationship between Working Capital Management and Profitability: Evidence from the United States. Business and Economics Journal, 20(10), 1-9.

10.Haq, I., Sohail, M., Zaman, K. and Alam, Z. (2011). The relationship between working capital management and profitability: a case study of cement industry in Pakistan. Mediterranean Journal of Social Sciences, 2(2), 365-372.

11.Mansoori, E., \& Muhammad, D. D. J. (2012). The effect of working capital management on firm's profitability: Evidence from Singapore. Interdisciplinary Journal of Contemporary Research in Business, 4(5), 472-486.

12.Mohamad, N. E. A., \& Saad, N. M. (2010). Working capital management: The effect of market valuation and profitability in Malaysia. International Journal of Business and Management, 5(11), 140-148.

13.Napompech, K. (2012). Effects of working capital management on the profitability of Thai listed firms. International Journal of Trade, Economics and Finance, 3(3), 227-232.

14.Nobanee, H., Abdullatif, M., AlHajjar, M. (2011). Cash Conversion Cycle and Firm's Performance of Japanese Firms. Asian Review of Accounting, 19(2), 147-156.

15.Raheman, A., Afza, T., Qayyum, A. and Bodla, M.A. (2010). Working capital management and corporate performance of manufacturing sector in Pakistan. International Research Journal of Finance and Economics, 47, 151-163.

16.Zariyawati, M.A, Annuar, M.N., \& Taufiq, H. (2009). Working Capital Management and Corporate Performances: Case of Malaysia. Journal of Modern Accounting and Auditing. 5(11), 47-54

17.Lou, Y.-I., \& Wang, M.-L. (2009). Fraud risk factor of the fraud triangle assessing the likelihood of fraudulent financial reporting. Journal of Business \& Economics Research (JBER), 7(2).

18.Raza, H., \& ul Haq, M. A. (2020). MODERATING EFFECT OF FINANCIAL SUSTAINABILITY ON ASSOCIATION BETWEEN FIRM'S FINANCIAL DETERMINANTS AND FIRM FINANCIAL DISTRESS: USING LOGIT AND ARTIFICIAL NEURAL NETWORK APPROACH. International Journal of Management, 11(08), 1510-1524.

19.Singhania, M., \& Mehta, P. (2017). Working capital management and firms' profitability: evidence from emerging Asian countries. South Asian Journal of Business Studies. 